Руслана Романишин,

кандидат педагогічних наук, доцент кафедри

фахових методик і технологій початкової освіти

ДВНЗ "Прикарпатський національний університет

імені Василя Стефаника"

(м. Івано-Франківськ, Україна)

Ruslana Romanyshyn,

Candidate of Pedagogical Sciences, Associate

Professor of the Department of Specialist Methods and

Technologies of Elementary Education State Institution,

Vasyl Stefanyk Precarpathian National University

(Ivano-Frankivsk, Ukraine)

ORCID ID 0000-0001-8480-2702

Удк $159.9: 519.6$

\title{
ВЛАСТИВОСТІ ДІЙ З ОБЧИСЛЕННЯ ТА ХАРАКТЕРИСТИКИ ОБЧИСЛЮВАЛЬНОЇ НАВИЧКИ
}

Анотація. У статті схарактеризовані обчислювальні дії з точки зору діяльнісного підходу у психології. Встановлено, що вони відносяться до розумових дій, які, за визначенням П. Гальперіна, $є$ підсумком перетворення зовнішньої матеріальної дії у план сприйняття, уявлень та понять. На основі досліджень П. Гальперіна та С. Степанової показано, що для формування повноцінної дії, зокрема обчислювальної, необхідна строга послідовність відпрацювання етапів. На кожному з цих етапів відбувається формування певних властивостей дії. Це пояснюється тим, що кожна більш висока форма утворюється на основі попередньої.

Описано шість напрямів, за якими відбувається зміна дії із зовнішньої, матеріальної - у розумову. Аналізуються структурні, динамічні, рівневі та психологічні параметри дії.

Усі ці характеристики враховані М. Бантовою при характеристиці повноцінної обчислювальної навички, до якої вчена віднесла правильність, усвідомленість, раціональність, узагальненість, автоматизм та міцність.

Ключові слова: обчислювальні дії, обчислювальна навичка, характеристики дії, характеристики обчислювальної навички.

\section{PROPERTIES OF CALCULATION ACTIONS AND CHARACTERISTICS OF COMPUTING SKILL}

\footnotetext{
Abstract. The article describes computational actions in terms of activity approach in psychology. It is established that they belong to mental actions, which according to P. Halperin are the result of the transformation of external material action into a plan of perception, ideas, and concepts. Based on the research of P. Halperin and S. Stepanova, it is shown that for the formation of a full action, in particular computational, a strict sequence of stages is required. At each of these stages, the formation of certain properties of action is done. This is because each higher form is built on the basis of the previous one.

Six directions are described in which there is a change of action from external, material, to mental. Structural, dynamic, level and psychological parameters of action are analyzed.

It is established that the structural features of the action include its completeness. This means that the action can be performed with a complete or incomplete composition of links. There may be a detailed execution of the action, or its reduction. The deployment of an action involves showing all its operations in their relationship. As you master the action, the operation is reduced and the action becomes contracted. The reduction can occur consciously or spontaneously. At spontaneous reduction the learner does not understand why it is possible to skip the operation; conscious reduction provides an opportunity to return from contracted forms of action to more complete ones.

The structural properties of a conscious action consist in its specific performance. It can be in the form of a continuous stream, or in a clear section of its individual links, or in its complete restoration, or with the omission of individual or even all links, where from the original data the subject immediately proceeds to the result. A completely contracted action is the action according to a formula, when from the initial data and the indication of the action with them the learner goes directly to the result, bypassing all intermediate transformations.

The dynamic parameters of action include force and time characteristics. Force characteristics include the magnitude and distribution of forces in different areas of action, and time characteristics, the pace and rhythm of action. It is shown that at the beginning of learning the pace should be slow enough so that the student can easily master the objective structure of the action and should start with a fully developed and artificially slowed down action.

All these characteristics are taken into account by M. Bantova in characterizing a full computing skill, to which the scientist attributed the correctness, awareness, rationality, generalization, automatism and strength.
}

Keywords: methods, research method, positioning strategy, leading university, rating. 


\section{ВСТУП}

Постановка проблеми. Концепцією Нової української школи математична компетентність визначена як одна з десяти ключових, якою повинен оволодіти учень початкової школи. Вона розуміється і як уміння застосовувати обчислення для розв'язання низки прикладних завдань у різних сферах людської діяльності. У цьому контексті розуміння суті та властивостей дій з обчислень є важливою для методики викладання математики.

Аналіз наукових досліджень і публікацій. Теоретичною основою дій з обчислень стали дослідження в галузі психології Л. Виготського, П. Гальперіна, С. Степанової, Н. Тализіної та ін. Зміст обчислювальних прийомів розглянуто у працях М. Бантової, Г. Бельтюкової, М. Богдановича, М. Будми-Горяєвої, О. Валльє, С. Волкової, А. Глазунової, Н. Гребенникової, Л. Дашевської, Т. Демидової, В. Єлисеевої, О. Івашової, Н. Істоміної, Н. Корсунської, Т. Кривошеї, І. Ліпатнікової, Н. Лишенко, Г. Мартинової, М. Моро, Н. Нікітіної, О. Онопрієнко, Н. Пиядін, Н. Рудовської, С. Скворцової, С. Степанової, Л. Сухіної, О. Тонких, Т. Фадєєвої, Т. Шевченко, В. Шпакової.

МЕТА І ЗАВДАННЯ ДОСЛІДЖЕННЯ полягають У розкритті властивостей дій з обчислення та характеристиці повноцінної обчислювальної навички.

\section{МЕТОДИ ДОСЛІДЖЕННЯ}

Методи дослідження: теоретичні - аналіз, систематизація та узагальнення науково-методичної літератури для визначення властивостей дій з обчислення.

\section{РЕЗУЛЬТАТИ ДОСЛІДЖЕННЯ}

Обчислювальні дії відносяться до розумових дій, які, за визначенням П. Гальперіна, є підсумком перетворення зовнішньої матеріальної дії у план сприйняття, уявлень та понять. Слідом за П. Гальперіним С. Степанова зазначила, що для формування повноцінної дії, зокрема обчислювальної, необхідна строга послідовність відпрацювання етапів і на кожному з них певних властивостей дії. Це зумовлено тим, що кожна більш висока форма утворюється на основі попередньої (Степанова М.А., 2002, с.29).

Н. Тализіна описала напрями, за якими відбувається перетворення, тобто зміна дії із зовнішньої, матеріальної у розумову.

Перший (найголовніший) напрям - зміна дії за формою. Його ще називають зміною плану або рівня. Учена виокремила такі його форми: матеріальна, матеріалізована, перцептивна, зовнішньомовна (усна або письмова), форма зовнішнього мовлення про себе, дія з уявленням, розумова форма (дія з понятям) (Тализіна Н.Ф., 2002, с.43).

Другий напрям характеризується переходом із зовнішнього плану у внутрішній. Ці зміни також пов'язані із зміною форми, однак становлять самостійну характеристику. Цей напрям характеризується п'ятьма зовнішніми формами (матеріальна, матеріалізована, перцептивна, зовнішньомовна (усна або письмова)) та трьома внутрішніми (форма зовнішнього мовлення про себе, дія з уявленням, розумова форма (дія з поняттям)). Шосту форму (зовнішнє мовлення про себе) можна розглядати як перехідну, яка поєднує в собі ознаки зовнішньої та внутрішньої форм (Тализіна Н.Ф., 2002, с.49).

Третій напрям - це зміна дії за мірою узагальненості. Н. Тализіна виокремила умови та діяльнісний механізм отримання заданої міри узагальненості дії за заданими властивостями. Було встановлено, що узагальнення йде тільки за тими властивостями, які увійшли до змісту орієнтувальної основи дії (ООД).

Четвертий напрям - зміна дії за повнотою операцій, що виконуються.

П'ятий напрям - зміна міри автоматизації і деяких інших характеристик дії.

Шостий напрям - міра самостійності дії, тобто перехід від розділеного виконання дії до самостійного (Тализіна Н.Ф., 2002, с.45).

Н. Тализіна зазначила, що останній зазначений напрям змін не відображений у працях П. Гальперіна, оскільки його розробкою займалася сама вчена, і вважала, що доцільніше для цього напряму зберегти назву, запропоновану Л. Виготським - перехід від соціального плану в індивідуальний.

Однак у експериментальних працях школи П. Гальперіна цей перехід мав місце. Так, в основній фазі поетапного формування здійснюється колективна робота дітей і тільки поступово вона стає індивідуальною (самостійною) (Тализіна Н.Ф., 2002, с.46). Ще однією характеристикою дії є її параметри. При класифікації параметрів дії Н. Тализіна слідом за П. Гальперіним виокремила групи первинних та другорядних параметрів. До первинних параметрів учені віднесли форму, міру узагальненості, міру розгорненості, міру засвоєності (автоматизація, легкість та інше), міру самостійності. Що стосується переходу дії із зовнішнього плану у внутрішній, то ця властивість не була позначена П. Гальперіним спеціальним терміном, але сам перехід систематично фіксувався. Тому Н. Тализіна запропонувала цю властивість назвати план дії (зовнішній план, або внутрішній план).

До другорядних властивостей П. Гальперін відносив: міцність, розумність, усвідомленість. Ці властивості або випливали з первинних (міцність, усвідомленість), або були результатом адекватності (або неадекватності) орієнтувальної основи дії (Тализіна Н.Ф., 2002, с.48).

Сукупність первинних характеристик дала можливість описати психологічний стан дії та діяльності при переході від матеріальних, (зовнішніх, розгорнених, не узагальнених, розділених, не автоматизованих) у розумові (внутрішні, узагальнені, згорнені, самостійні, автоматизовані). Типовий стан дії становить етап її засвоєння.

Серед параметрів дії П. Гальперін виокремив структурні, динамічні, рівневі та психологічні.

Описуючи структурні характеристики дії, П. Гальперін відзначив дві особливості побудови цілеспрямованої дії. 3 одного боку, це розділення орієнтувальної та виконавчої частин, а з іншого - це опосередкованість дії своєрідною психічною характеристикою - схемою її орієнтувальної основи. 
До структурних особливостей дії відноситься її повнота. Це означає, що дія може виконуватися з повним або неповним складом ланок. Тобто може спостерігатися розгорнене виконання дії або її скорочення. Розгорнутість дії передбачає показ усіх ї̈ операцій у їх взаємозв'язку. По мірі засвоєння дії/операції скорочуються, дія стає згорненою. Скорочення може відбувається свідомо або стихійно. При стихійному скороченні учень не розуміє, чому можна пропустити операцію; свідоме скорочення забезпечує можливість повернення від скорочених форм дії до більш повних (Степанова М.А., 1998, с.96).

Структурні властивості усвідомленої дії полягають у її характерному виконанні. Воно може бути як у вигляді суцільного потоку, або в чіткому розділі його окремих ланок, або в повному його відновленні, або з пропуском окремих, а то й усіх ланок, де від вихідних даних суб'єкт відразу переходить до результату. Повністю скорочена дія - це дія за формулою, коли від вихідних даних і вказування на дію з ними безпосередньо переходять до результату, минаючи всі проміжні перетворення.

До динамічних параметрів дії П. Гальперін відносить силові та часові характеристики. До силових належить величина і розподіл зусиль на різних ділянках дії, а до часових - темп та ритм дії. Учений наголошував на тому, що на початку навчання темп повинен бути повільним настільки, щоб учень спокійно міг оволодіти об'єктивною структурою дії, і починати слід з повністю розгорненої та штучно уповільненої дії (Степанова М.А., 1998, с. 100).

Відпрацювання кожної нової дії відбувається на матеріальному або матеріалізованому рівнях. На матеріальному рівні дія відбувається безпосередньо з самими речами, а на матеріалізованому - з їх замінниками. На наступному рівні - у гучному мовленні задача розв'язується вголос. Пізніше дія відбувається "в зовнішньому мовленні про себе" та у “прихованому мовленні".

П. Гальперін, як зазначила М. Степанова, пізніше виокремив як самостійні рівнів дію у “внутрішньому мовленні” та дію у “прихованому мовленні". На його думку, рівень внутрішнього мовлення є проміжним між "зовнішнім мовленням про себе" та "прихованим мовленням". Внутрішнє мовлення - таке, у якому звуко-моторний компонент унаслідок повної автоматизації пропускається нижче порогу свідомості, а його мовні значення у свідомості зберігаються. У внутрішньому мовленні багато що “мається на увазі", а у прихованому мовленні вже все "мається на увазі”. Саме це приховане мовлення і є думкою.

М. Степанова зазначила, що П. Гальперін виокремлював між зовнішньопредметним (матеріальної або матеріалізованої дії) та мовним (виконання дії у голосному мовленні) етапами ще й перцептивний етап, коли дія виконується з тими самими речами, що й на попередньому етапі, але без рук, речі перебувають перед очами (Степанова М.А., 1998, с. 101).

До психологічних характеристик дії П. Гальперін відніс узагальненість, розумність, усвідомленість та критичність (Степанова М.А., 1998, с. 102).

Під узагальненістю вчений розумів діапазон варіантів умов, в яких дія може успішно виконуватися. Загалом узагальнення $€$ засобом виокремлення істотних умов дії від неістотних, узагальнити дію означає відокремити із різноманітних властивостей об'єкта саме ті, які необхідні для виконання цієї дії.

На матеріальному етапі узагальнення ще не $є$ абстракцією, а лише виокремленням істотних властивостей об'єкта, що дає можливість перейти на етап голосного мовлення та формує передумови виникнення абстракції (Степанова М.А., 1998, с.103).

Критичність дії М. Степанова визначає як оцінку учнем відповідності посилок дії об'єктивній дійсності. Критичність дії передбачає уміння розрізняти слова про речі і самі речі та оцінювати речі не за словам про них, а за адекватним для них критерієм. Важливим для розуміння психологічних механізмів дії, на думку вченої, є зв'язок критичності дії з їі розумністю.

Розумність дії передбачає її орієнтацію на істотні властивості. Також вона має стосунок до розгорненості, яка разом з узагальненістю забезпечують розумність дії, іншим виразом якої є її гнучкість (Степанова М.А., 1998, с. 103).

При визначенні та характеристиці обчислювальної навички важливе місце відводиться оволодінню обчислювальним прийомом, під яким С Скворцова розуміє систему операцій, виконання яких призводить до знаходження результату арифметичної дії (Скворцова С., 2017, с. 185).

Визначаючи обчислювальну навичку як високий ступінь оволодіння обчислювальними прийомами, М. Бантова вказала на характеристику повноцінної обчислювальної навички, до якої відносяться правильність, усвідомленість, раціональність, узагальненість, автоматизм та міцність. Як бачимо, така характеристика збігається зі структурними характеристиками дії, що представлена в дослідженнях психологів П. Гальперіна, Н. Тализіної, М. Степанової.

Правильністю вчена М. Бантова називає здатність правильно знаходити учнем результат арифметичної дії над заданими числами, тобто правильно обирати та виконувати операції, які входять до складу прийому (Бантова М.А., 1993, с. 39). Усвідомленість науковець визначає як здатність учня свідомо на основі здобутих знань обирати операції та встановлювати порядок їх виконання. Важливою характеристикою цього показника є те, що учень на будь-якому етапі обчислень може пояснити вибір та доцільність застосування обраного способу обчислення. Учена слідом за П. Гальперіним передбачає поступове згортання у процесі засвоєння (Бантова М.А., 1993, с. 39).

Раціональність характеризується здатністю обирати для певного випадку найбільш раціональний прийом, тобто ті з можливих операцій, які легше і швидше призводять до результату арифметичної дії. За поясненням вченої, така якість навички може проявлятися тоді, коли для певного випадку існують різні прийоми знаходження результату. Тобто учень озброєний достатнім арсеналом знань, які уможливлюють йому конструювати декілька прийомів і обирати серед них раціональний. Ця характеристика безпосередньо пов'язана з усвідомленістю. 
Узагальненістю називається здатність застосовувати прийом обчислення до найбільшої кількості випадків, тобто здатність переносити прийом на нові випадки. Узагальненість, як і раціональність, пов'язана з усвідомленістю, оскільки спільним для різних способів обчислення буде прийом, основою якого є одні й ті ж теоретичні положення.

При визначенні автоматизму, або згорнутості, М. Бантова також опирається на дослідження вчених-психологів, зокрема П. Гальперіна, і називає здатність виконувати операції швидко і в згорнутому виді. При цьому учень завжди може повернутися до пояснення вибору системи операцій. Високий ступінь автоматизму повинен бути досягнуто для випадків додавання та віднімання одноцифрових чисел без переходу через розряд, окремих випадків 3 переходом через розряд (9+6; 15 - 9) та табличних випадків множення та ділення. Зазначається, що учень повинен досягти рівня, коли з двома числами він зразу співвідносить третє число, що є результатом арифметичної дії, не виконуючи окремих операцій.

Щодо інших випадків арифметичних дій, то тут відбувається часткова автоматизація обчислювальних навичок. Це проявляється, коли учень швидко визначає та виконує систему операцій, не пояснюючи, чому обрав саме ці і як виконав кожну з них. Учена зазначила, що в цьому випадку можна стверджувати про автоматизацію обчислювальних навичок. У цьому плані усвідомленість та автоматизм не $є$ протилежними характеристиками. Вони виступають у єдності, бо при згорнутому виконанні операцій усвідомленість зберігається, а обґрунтування вибору системи операцій відбувається згорнуто у плані внутрішнього мовлення (Бантова М.А., 1993, с. 39). Завдяки цьому учень може в будь-який момент повернутися до розгорнутого обґрунтування вибору системи операцій.

Міцністю М. Бантова називає таку якість, коли учень зберігає сформовану обчислювальну навичку протягом тривалого часу (Бантова М.А., 1993, с. 39).

\section{ВИСНОВКИ ТА ПЕРСПЕКТИВИ ПОДАЛЬШИХ ДОСЛІДЖЕНЬ}

Формування повноцінних обчислювальних умінь та обчислювальної навички зумовлює усвідомлення та розуміння того, що цей процес вимагає послідовності відпрацювання етапів і на кожному 3 них певних властивостей дії. Це пояснюється тим, що кожна більш висока форма утворюється на основі попередньої. Перспективу подальших досліджень вбачаємо у використанні психологічних розвідок при побудові методичної системи формування обчислювальних навичок у молодших школярів.

\section{СПИСОК ВИКОРИСТАНИХ ДЖЕРЕЛ}

Бантова, М. А. (1993). Система формирования вычислительных навыков. Начальная школа. № 11. 38-44.

Скворцова, С. А. (2017). Методическая система формирования вычислительных навыков. Инновационные технологи обучения физико-математическим и профессионально-техническим дисциплинам: Материалы IX Международной научно-практической интернет-конференции. 185-186.

Степанова, М.А. (1998). Представления о параметрах умственных действий в психологическом учении П. Я. Гальперина. Вестник Московского университета. Серия 14. Психология. №3. 95-103.

Степанова, М. А. (2002). Место теории П. Я. Гальперина в психологической концепции деятельности. Вопросы психологии. № 5. 28-41.

Талызина, Н. Ф. (2002). Развитие П. Я. Гальпериным деятельностного подхода в психологии. Вопросы психологии. №5. 42-49.

\section{REFERENCES}

Bantova, M. A. (1993). Sistema formirovaniya vychislitel'nykh navykov. Nachal'naya shkola, 11, 38-44.

Skvortsova, S. A. (2017). Metodicheskaya sistema formirovaniya vychislitel'nykh navykov. Innovatsionnyye tekhnologi obucheniya fizikomatematicheskim i professional'no-tekhnicheskim distsiplinam: Materialy ÍKH Mezhdunarodnoy nauchno-prakticheskoy internetkonferentsii, 185-186.

Stepanova, M. A. (1998). Predstavleniya o parametrakh umstvennykh deystviy v psikhologicheskom uchenii P.YA.Gal'perina. Vestnik Moskovskogo universiteta. Seriya 14. Psikhologiya, 3, 95-103.

Stepanova, M. A. (2002). Mesto teorii P.YA.Gal'perina v psikhologicheskoy kontseptsii deyatel'nosti. Voprosy psikhologii, 5, $28-41$.

Talyzina, N. F. (2002). Razvitiye P.YA.Gal'perinym deyatel'nostnogo podkhoda v psikhologii. Voprosy psikhologii, 5, $42-49$.

Статтю подано до редколегії 07.05.2020 p.

Рекомендовано до друку 22.05.2020 p. 